\title{
SENTIMENT ANALYSIS OF COSMETIC REVIEW USING NAIVE BAYES AND SUPPORT VECTOR MACHINE METHOD BASED ON PARTICLE SWARM OPTIMIZATION
}

\author{
Zulia Imami Alfianti1 ${ }^{*}$, Deni Gunawan², Ahmad Fikri Amin ${ }^{3}$ \\ 1,2Sistem Informasi \\ Universitas Bina Sarana Informatika \\ www.bsi.ac.id \\ 1imamizulia@gmail.com,2deni.deg@bsi.ac.id \\ ${ }^{3}$ Sistem Informasi \\ ${ }^{3}$ Institut Transportasi dan Logistik Trisakti \\ http://itltrisakti.ac.id \\ 3ahmadvikry30@gmail.com
}

\begin{abstract}
Abstrak
Analisis sentimen adalah sebuah bidang pendekatan yang pemecahan masalahnya dengan menggunakan tinjauan dari berbagai sudut pandang ilmu secara relevan. Membaca review sebelum membeli produk merupakan hal yang sangat penting untuk mengetahui kekurangan dan kelebihan produk yang akan kita gunakan, selain itu membaca review kosmetik dapat mengetahui kualitas merek kosmetik tersebut layak atau tidak untuk digunakan. Sebelum konsumen memutuskan untuk membeli kosmetik sebaiknya konsumen mengetahui secara rinci produk yang akan dibeli, hal ini dapat dipelajari dari testimoni atau hasil review dari konsumen yang sudag nenbeli dan menggunakan produk sebelumnya. Jumlah review yang pastinya sangat banyak menjadikan konsumen enggan membaca review. Akhirnya ulasan/review tersebut menjadi tidak berguna. Untuk itu penulis mengklasifikasikan berdasarkan class positif dan class negative, agar konsumen dapat mengetahui perbandingan produk secara cepat dan tepat. Penerapan optimasi Particle Swarm Optimization (PSO) dapat mengingkatkan akurasi Algoritma Support Vector Machine (SVM) dan Naïve Bayes (NB) dapat mengingkatkan akurasi dan memberikan solusi terhadap permasalahan klasifikasi review agar lebih akurat dan optimal. Perbandingan akurasi yang dihasilkan dari pengujian data ini yaitu: Algoritma SVM sebesar 89.20\% dan AUC sebesar 0.973, kemudian dibandingkan dengan SVM berbasis PSO dengan akurasi $94.60 \%$ dan AUC sebesar 0.985. Hasil pengujian data untuk algoritma NB akurasinya adalah 88.50\% dan AUC yaitu 0.536, kemudian dibandingkan akurasinya dengan NB berbasis PSO sebesar 0.692. Dalam perhitungan tersebut membuktikan bahwa penerapan optimasi PSO dapat meningkatkan akurasi dan memberikan solusi lebih akurat dan optimal.
\end{abstract}

Kata Kunci: Analisis Sentimen, Nä̈ve Bayes, SVM, PSO, Review Kosmetik

\begin{abstract}
Sentiment analysis is an area of approach that solves problems by using reviews from various relevant scientific perspectives. Reading a review before buying a product is very important to know the advantages and disadvantages of the products we will use, besides reading a cosmetic review can find out the quality of the cosmetic brand is feasible or not be used. Before consumers decide to buy cosmetics, consumers should know in detail the products to be purchased, this can be learned from the testimonials or the results of reviews from consumers who have bought and used the previous product. The number of reviews is certainly very much making consumers reluctant to read reviews. Eventually, the reviews become useless. For this reason, the authors classify based on positive and negative classes, so consumers can find product comparisons quickly and precisely. The implementation of Particle Swarm Optimization (PSO) optimization can improve the accuracy of the Support Vector Machine (SVM) and Naïve Bayes (NB) algorithm can improve accuracy and provide solutions to the review classification problem to be more accurate and optimal. Comparison of accuracy resulting from testing this data is an SVM algorithm of $89.20 \%$ and AUC of 0.973 , then compared to SVM based on PSO with an accuracy of $94.60 \%$ and AUC of 0.985 . The results of testing the data for the NB algorithm are $88.50 \%$ accuracy and AUC is 0.536 , then the accuracy is compared with the PSO based NB for 0.692. In these calculations prove that the application of PSO optimization can improve accuracy and provide more accurate and optimal solutions.
\end{abstract}

Keywords: Sentiment Analysis, Naive Bayes, SVM, PSO, Cosmetics Review. 


\section{INTRODUCTION}

The rapid progress of technology in the world, coupled with the behavior of individuals who are very dependent on technology. Current technology has indeed entered into all circles. This encourages all aspects of having innovation in various activities. Nowadays a lot of people pour opinions on online media because they are easy to be a means of public opinion. One example is the opinion/review of the product. Read a review before buying a product is very important to know the advantages and disadvantages of the product to be used, in addition to reading cosmetic reviews can also find out the quality of the cosmetic brand can determine the quality of the cosmetic brand is feasible or not be used. Before consumers decide to buy cosmetics, consumers should know in detail the products to be purchased, this can be learned from testimonials and opinions or the results of reviews from consumers who have bought and used the product before.

The activity of reading reviews which are certainly very many are generally very timeconsuming consumers, so the review becomes useless. In this case, the research aims to assess cosmetic reviews by classifying based on positive and negative classes so that consumers can find out product reviews from other consumers precisely and quickly.

Sentiment analysis consists of natural language processing, text analysis, and linguistic computation to identify sentiments and documents (Vinodhini \& Chandrasekaran, 2016). In this case, the writer wants to do a sentiment analysis aimed at knowing the level of accuracy of test data. Classification techniques commonly used for review sentiment analysis include Naïve Bayes, Support Vector Mabe (SVM, and K-Nearest Neighbor (KNN). Several studies have been conducted in doing sentiment calcification of reviews available online, including text mining for sentiment analysis of film reviews using the KMean Algorithm, Sentiment analysis on consumer reviews using Naïve Bayes with Chi-Square feature selection for traditional food location recommendations.

\section{MATERIALS AND METHODS}

\section{Research Design}

Research is an organized investigation that is generally carried out to present information and solve a problem. The research method used by the author uses experimental research methods.

\section{Data processing}

The data examined using data obtained from the website femaledaily.com, the data was taken from a review of cosmetics from four wellknown cosmetic brands namely Maybelline, Emina, and Wardah. The data is used by the author to produce a dataset that is grouped into positive and negative.

Review data used in a text mining processing of 1000 data taken from each product based on cosmetics took. From 1000 datasets there are 500 positive reviews and 500 negative reviews. Also, it needs careful in separating words that contain foreign languages and ambiguous meanings so that the comments are not taken by the author. Positive comments based on user information that will buy the product again apart from positive meaningful words including, good, suitable, affordable, good, and so on. Negative comments contain information that the user will not buy the product again. Comments are neutral meaning comments that provide a light that users might buy the product again.

\section{Proposed Method}

The method proposed by the author uses two algorithms, namely Support Vector Machine (SVM) and Naive Bayes, each using the Particle Swarm Optimization (PSO) feature selection (Kristiyanti, 2015). The use of PSO will produce a higher level of accuracy. SVM is a relatively new technique for making predictions, both in the case of classification and regression (Mahendrajaya et al., 2019). The Vector Machine Support algorithm is a method that works well on more complex data sets, but SVM also has a problem in determining parameters (Buntoro, 2017). In previous calculations, SVM always gets the highest accuracy, because this method recognizes the distribution of word patterns in sentences (Buntoro \& Asrofi, 2016) Classification using the Naive Bayes method produces good accuracy, but still makes the least error during the process classification of data whose share of sentiments is not balanced (Rustiana \& Rahayu, 2017). Because using unbalanced data will cause minority class data that is incorrectly classified as majority class data. In the end, it makes a big difference in value. This can be proven by testing the parameter values and selecting the value that produces the best accuracy. For this reason, the authors conducted a sentiment analysis using the two methods above, namely SVM and Naive Bayes based on PSO. Data analysis media used were Rapid Miner Studio 9.1 (Faid et al., 2019) 


\section{RESEARCH RESULTS AND DISCUSSION}

Training data used when testing data was taken from a website about cosmetics namely femaledialy.com using Rapidminer Studio 9.1. Data retrieval is limited based on products that have the most comments from three brands that have the highest rating on femaledialy.com. The dataset obtained through manual retrieval is not all categorized as positive and negative classes. Therefore, classification needs to be done manually or called the labeling process to provide positive or negative labels. From the overall data which amounted to 1000 reviews, there were 500 positive data and 500 negative data. The data has gone through the preprocessing stage then testing and training of the dataset are performed so that the accuracy and AUC (Area Under Curve) values of each algorithm are obtained. The following will be explained in more detail about the research results obtained. The process of determining part of a sentence as a member of a positive or negative class based on the calculation value of SVM and Naive Bayes, if the result of that sentence for a positive class is greater than the negative class, then the sentence is included in the positive class, if the probability for a positive class is smaller than the negative class, then the sentence is included in the negative class.

\section{A. Results Evaluation Analysis and Model Validation}

In-text mining which is the application of concepts and data mining techniques to look for patterns in the text (Chandra et al., 2016), validation serves to obtain a prediction using a predetermined model. Then compare the results with the results that have been previously known. This is the most important step in the process of building a model. Cross-Validation is a validation technique by dividing data randomly into $\mathrm{k}$ sections and each part will be classified (Kusmira, 2019). In Cross-Validation, a fixed number of folds or partitions of data must be determined by themselves (Kusmira, 2019). The standard way to predict the error rate from learning techniques of a fixed data sample is to use ten-fold crossvalidation.

The results of the model testing conducted are classifying negative comments and positive comments using SVM and SVM+PSO, NB, and $\mathrm{NB}+\mathrm{PSO}$ to find the best accuracy value in the RapidMiner framework with the model design in figure 1.

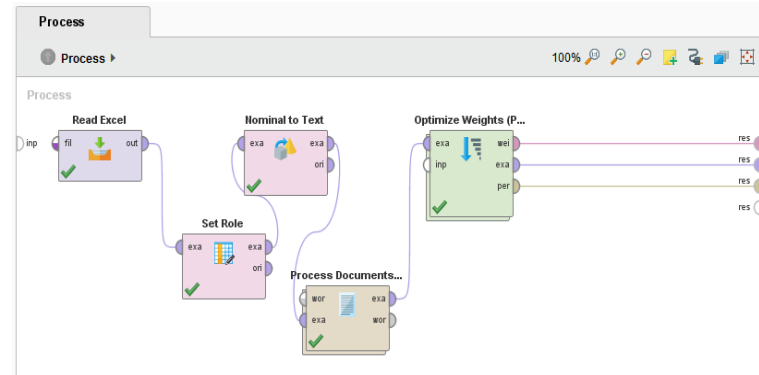

Figure 1. Design SVM PSO Model

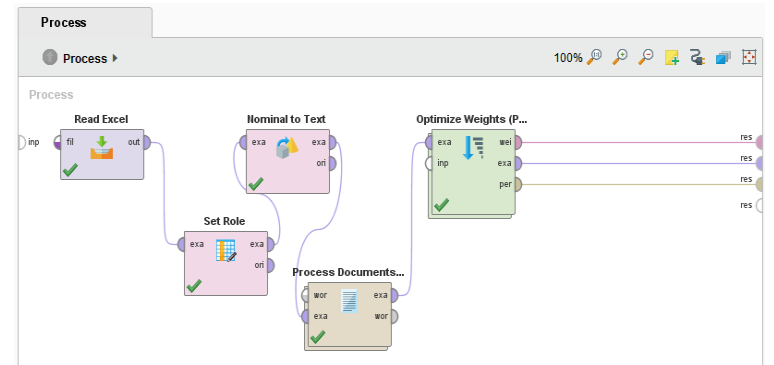

Figure 2. Design Naive Bayes PSO Model

In Figure 1 and Figure 2 which is a test using RapidMiner with PSO and Naïve Bayes SVM Algorithm using 500 positive data and 500 data that have gone through the preprocessing process.

\section{B. Testing Results for Support Vector Machine Method Models}

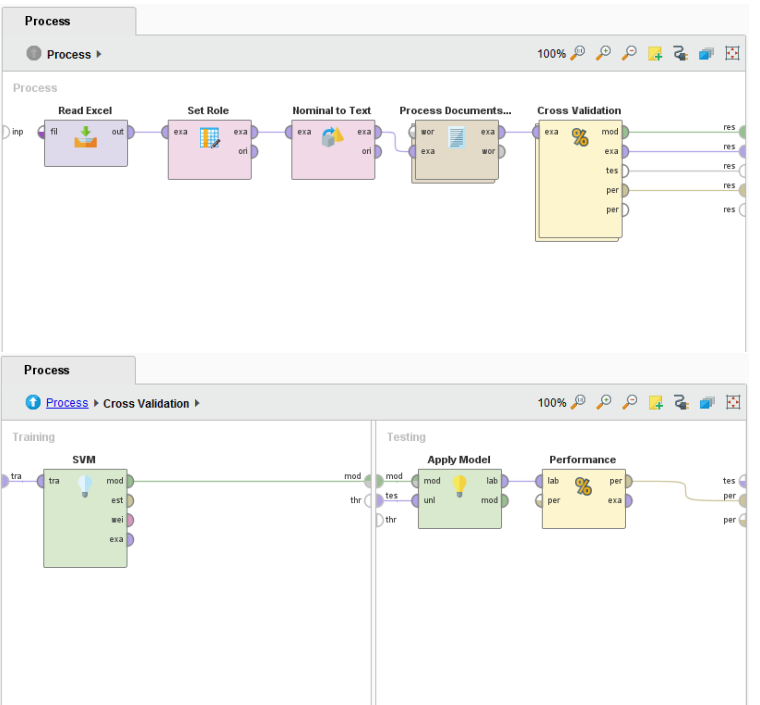

Figure 3. Model Testing Support Vector Machine

In tests conducted as shown in Figure 3. used is clean data that has been through preprocessing. Process document from data that is processing documents from the data repository that has been created. The following will describe 
the calculation at the level of accuracy, class precision, and class recall.

\section{ROC Curve}

The ROC (Receiver Operating Characteristic) curve is another way to evaluate accuracy and calcification visually. A graph A ROC graph is a plot of two manages with positive proportions of one of the $\mathrm{X}$-axes and positive true on the $\mathrm{Y}$-axis. The results of calculations on the ROC curve, illustrate the ROC curve for the SVM algorithm (Rinawati, 2013). It can be concluded that one point on the ROC curve is better than the other if the direction of the transverse line from left to bottom right is in the (Pudjiarti, 2016). The ROC SVM curve with an AUC (Area Under Curve) value of 0.918 where the diagnosis results are Excellent Classification. The following can be seen in the ROC SVM Curve in Figure 4.

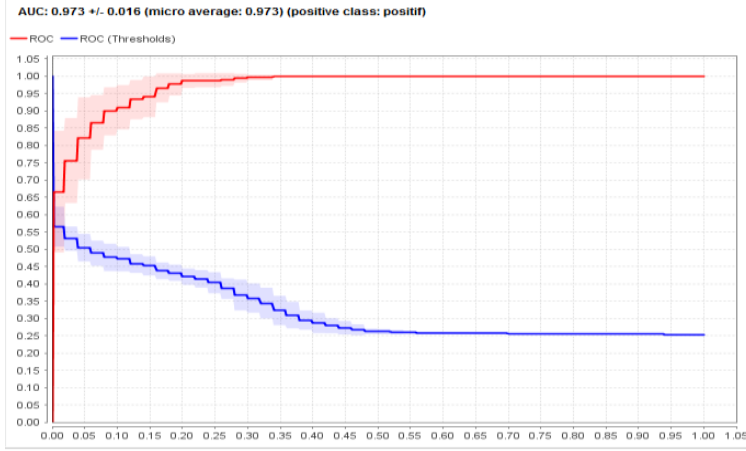

Figure 4. ROC Curve Support Vector Machine

Information:

Accuracy $0.90-1.00=$ Excellent classification

Accuracy $0.80-0.90=$ Good classification Accuracy $0.70-0.80=$ Fair classification Accuracy $0.60-0.70=$ Poor classification Accuracy $0.50-0.60=$ Failure

\section{Confusion Matrix}

Providing decisions obtained in training and testing, the confusion matrix provides classification performance based on true or false objects. Confusion Matrix contains actual and predicted information on the classification system. This explanation can be seen as the results in table 1. Accuracy : $89.20 \%+/-3.74 \%$ (micro average : $89.20 \%)$

Table 1. Confusion Matrix Support Vector Machine

\begin{tabular}{llll}
\hline & $\begin{array}{l}\text { True } \\
\text { Negative }\end{array}$ & $\begin{array}{l}\text { True } \\
\text { Positive }\end{array}$ & $\begin{array}{l}\text { Class } \\
\text { Precision }\end{array}$ \\
\hline Pred. Negative & 470 & 78 & $86.77 \%$ \\
\hline Pred. Positive & 30 & 422 & $93.36 \%$ \\
\hline & $94.00 \%$ & $84.00 \%$ & \\
\hline
\end{tabular}

Accuracy $=\frac{T P+T N}{T P+T N+F P+F N}=0,892$

Sencitifity $=\frac{T P}{T P+F N}=0.844$

Specificity $=\frac{T N}{T N+F P}=0.94$

$P P V=\frac{T P}{T P+F P}=0.9333$

$N P V=\frac{T N}{T N+F N}=0.857$

The explanation obtained from table 1 is the accuracy obtained, namely $89.20 \%$ of the 500 positive review data and 500 negative review data on cosmetic reviews on the website femaledaily.com which took positive and negative reviews from three cosmetic brands. Based on the results listed in table 1 , the review data produced by RapidMiner with the SVM model shows that the classification for negative reviews that corresponds to predictions is 470 . Positive review data included in negative predictions is 78 . Negative review data included in positive predictions namely 30 and the positive review data included in the positive prediction is 422 .

\section{Model Testing Results of Support Vector Machine Method based on Particle Swarm Optimization.}

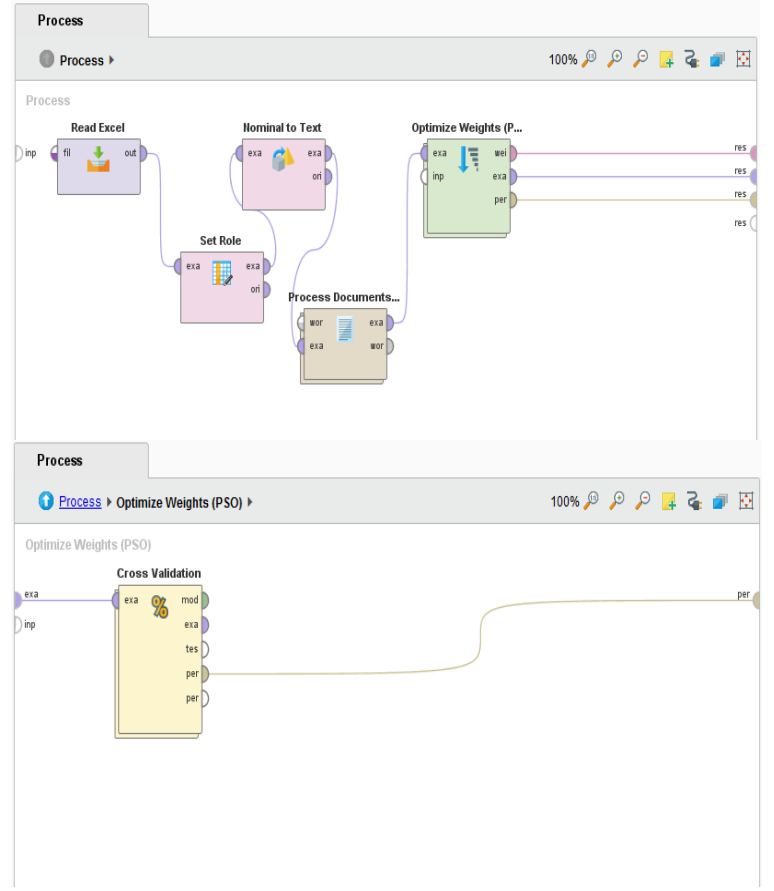




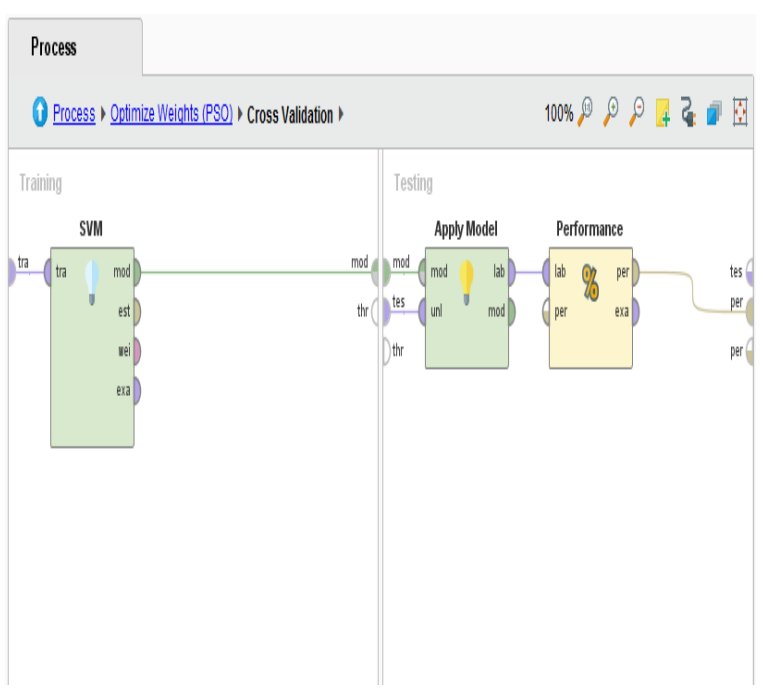

Figure 5. Model Testing Support Vector Machine based on Particle Swarm Optimization

Figure 5. It is a testing process using the SVM method based on PSO using 500 positive data and 500 negative data. The first step is to use the Nominal to Text operator to change the selected nominal attribute type to text. Then using the SVM method, optimization is done using PSO.

The results of testing the training data for the SVM method based on PSO use the Set Role that functions to determine the fields in the class and then given optimization using PSO so that the resulting accuracy is higher. Measurement of accuracy will be described through the ROC Curve and Confusion Matrix shown there is a picture 6 .

\section{ROC Curve}

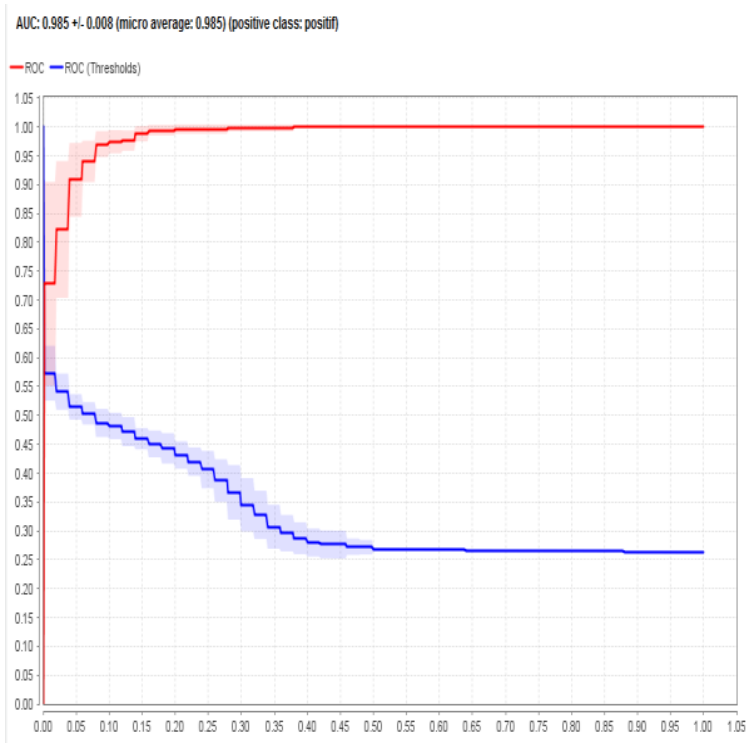

Figure 6. ROC Curve Support Vector Machine based on Particle Swarm Optimization
The ROC curve generated based on the test data in Figure 6, shows that there is an increase in the accuracy value when using the SVM based on the PSO method which is $94.60 \%$ and the AUC is 0.985 .

\section{Confusion Matrix}

Accuracy : $94.60 \%+/-1.90 \%$ (micro average : $94.60 \%)$

Table 2. Confusion Matrix Support Vector Machine Particle Swarm Optimization

\begin{tabular}{llll} 
& \multicolumn{3}{c}{ Particle Swarm Optimization } \\
& $\begin{array}{l}\text { True } \\
\text { Negative }\end{array}$ & $\begin{array}{l}\text { True } \\
\text { Positive }\end{array}$ & $\begin{array}{l}\text { Class } \\
\text { Precision }\end{array}$ \\
\hline $\begin{array}{l}\text { Pred. } \\
\text { Negative }\end{array}$ & 470 & 24 & $95.14 \%$ \\
\hline $\begin{array}{l}\text { Pred. } \\
\text { Positive }\end{array}$ & 30 & 476 & $94.07 \%$ \\
\hline & $94.00 \%$ & $95.20 \%$ & \\
\hline
\end{tabular}

Table 2. above is the result of SVM testing using PSO which produces a precision class such as the one listed in the table than from the results above can be calculated Accuracy, Sensitivity, specificity, PVP, and NPV as follows:

Accuracy $=\frac{T P+T N}{T P+T N+F P+F N}=0,946$

Sencitifity $=\frac{T P}{T P+F N}=0.822$

Specificity $=\frac{T N}{T N+F P}=0.634$

$P P V=\frac{T P}{T P+F P}=0.692$

$N P V=\frac{T N}{T N+F N}=0.780$

The training data used consisted of 500 positive review data and 500 negative review data on the femaledaily.com cosmetic website. The data has been through several stages of processing on RapidMiner with the SVM model based on PSO, classified for negative reviews according to predictions which are 470. Positive review data included in negative predictions is 24. Negative review data included in positive predictions is 30 and the positive review data included in the prediction is 476 .

\section{Naive Bayes Method (NB) Model Test Results}




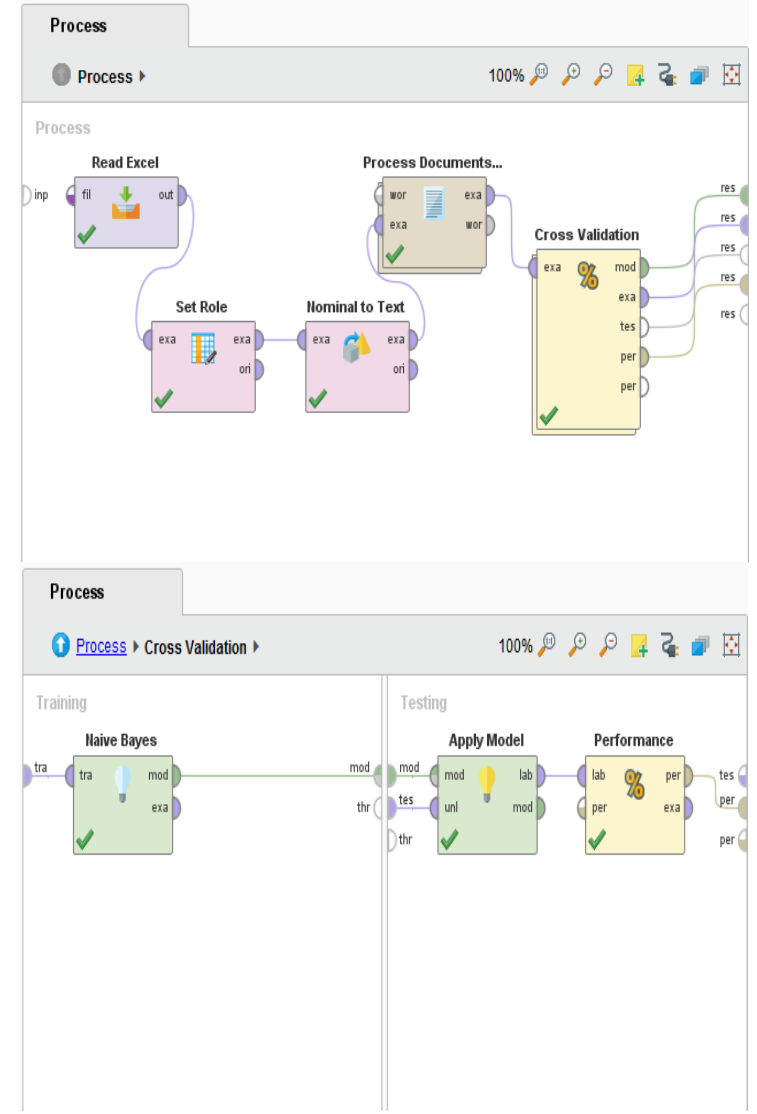

Figure 7. Model Testing Naive Bayes

The results of testing the data in Figure 7 with the Naive Bayes method. The results of the calculation of accuracy, class precision, and class recall are as follows.

\section{ROC curve}

The Naive Bayes ROC curve shown in Figure 8 can express the confusion matrix of Table 3. The ROC curve is interpreted as false positive for horizontal lines and True positive for vertical lines with AUC value $=0.536$.

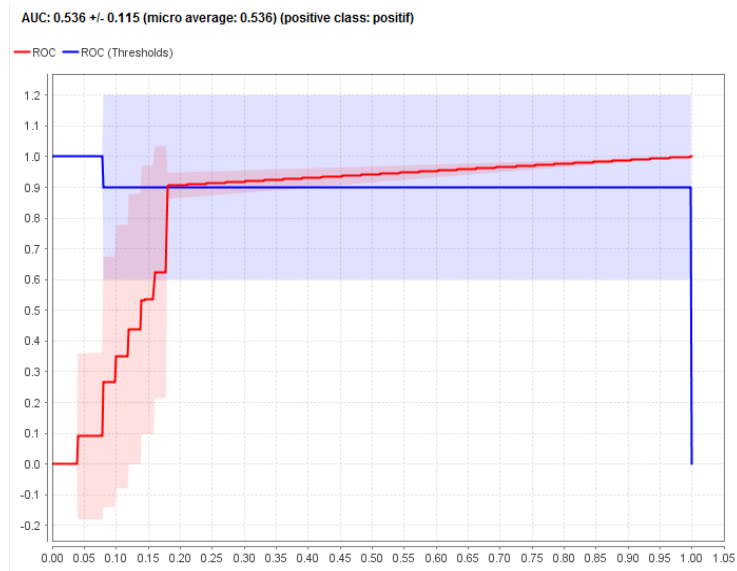

Figure 8. Naive Bayes ROC Curve
From the picture of the Naïve Bayes ROC curve in Figure 8. It can be seen that the blue curve is better than the red curve. In this way, we more easily find out whether or not the algorithm is in this calculation.

\section{Confusion Matrix}

Providing decisions obtained in training and testing, the confusion matrix provides an assessment of classification performance based on true or false objects. The confusion matrix contains information (actual) and predicted (predicted) in the classification system.Accuracy : $88.50 \%+/-$ $2.59 \%$ (micro average : $88.50 \%$ )

Table 3. Confusion Matrix with the Naive Bayes

\begin{tabular}{llll}
\hline \multicolumn{4}{c}{ Model } \\
& $\begin{array}{l}\text { True } \\
\text { Negatif }\end{array}$ & $\begin{array}{l}\text { True } \\
\text { Positif }\end{array}$ & $\begin{array}{l}\text { Class } \\
\text { Precision }\end{array}$ \\
\hline Pred. Negative & 437 & 52 & $89.37 \%$ \\
\hline Pred. Positive & 63 & 448 & $87.76 \%$ \\
\hline & $87.40 \%$ & $89.60 \%$ & \\
\hline
\end{tabular}

Table 3. above is the result of SVM testing using PSO which produces a class precision such as the one listed in the table than from the results above can be calculated Accuracy, Sensitivity, specificity, PVP, and NPV as follows:

Accuracy $=\frac{T P+T N}{T P+T N+F P+F N}=0,855$

Sencitifity $=\frac{T P}{T P+F N}=0.896$

Specificity $=\frac{T N}{T N+F P}=0.874$

$P P V=\frac{T P}{T P+F P}=0.876$

$N P V=\frac{T N}{T N+F N}=0.8936$

Positive reviews and 500 negative reviews data based on cosmetics reviews on the website femaledaily.com Review data generated by RapidMiner with the Naive Bayes model shows that the classification for negative reviews that match predictions is 437. Positive review data included in negative predictions is 52 . Data review negative which is included in the positive prediction is 63 and the positive review data included in the positive prediction is 448 . 


\section{E. Testing the Model Naive Bayes Method based on Particle Swarm Optimization}

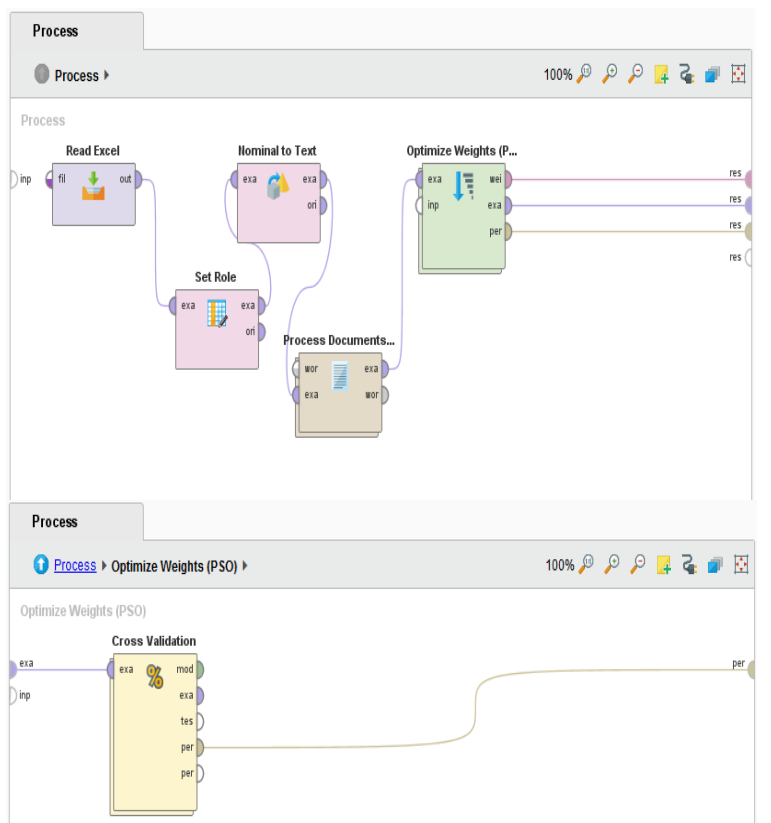

Figure 9. Naive Bayes Testing Model-based on Particle Swarm Optimization

The test results in Figure 9 using the Naive Bayes model based on PSO obtained the results in table 4 .

\section{ROC curve}

The calculation results are visualized with the ROC curve for the Naive Bayes algorithm based on PSO. The ROC curve in Figure 10 expresses the Confusion Matrix from table 4. Horizontal lines are False Positive and for vertical lines True Positive.

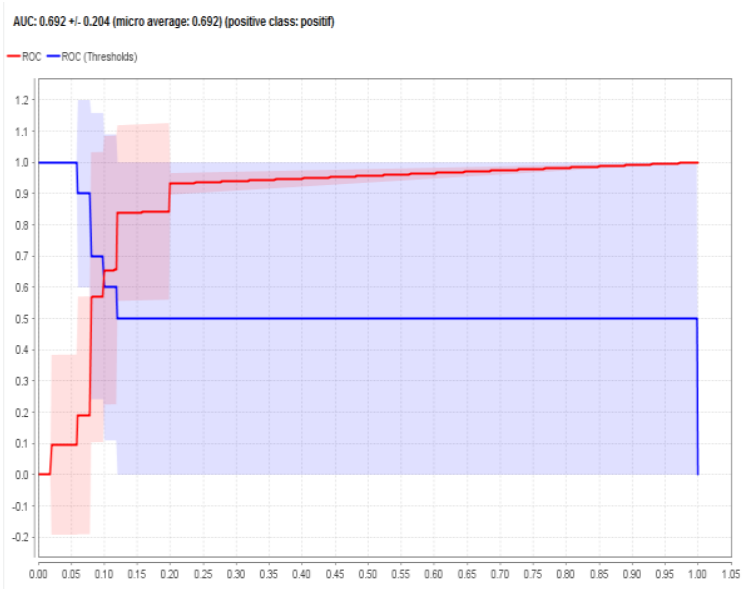

Figure 10. Particle Swarm Optimization-based Naive Bayes ROC curve
The AUC value generated from Figure 10 above is 0.692, which is included in the Excellent classification.

\section{Confusion Matrix}

Accuracy: $91.10 \%+/-3.75 \%$ (micro average : $91.10 \%)$

Table 4. Confusion Matrix Naive Bayes Particle Swarm Optimization

\begin{tabular}{llll}
\hline & $\begin{array}{l}\text { True } \\
\text { Negative }\end{array}$ & $\begin{array}{l}\text { True } \\
\text { Positive }\end{array}$ & \\
\hline Pred. Negative & 453 & 42 & $91.52 \%$ \\
\hline Pred. Positive & 47 & 458 & $90.69 \%$ \\
\hline & $90.60 \%$ & $91.60 \%$ & \\
\hline
\end{tabular}

Table 4. above is the result of SVM testing using PSO which produces the precision classes as listed in the table. Then the results of the above can be calculated Accuracy, Sensitivity, specificity, PVP, and NPV as follows:

$$
\begin{aligned}
& \text { Accuracy }=\frac{T P+T N}{T P+T N+F P+F N}=0,911 \\
& \text { Sencitifity }=\frac{T P}{T P+F N}=0.916 \\
& \text { Specificity }=\frac{T N}{T N+F P}=0.906 \\
& P P V=\frac{T P}{T P+F P}=0.9069 \\
& N P V=\frac{T N}{T N+F N}=0.9152
\end{aligned}
$$

The negative review data that fits the prediction is 453 data. The positive review data included in the negative prediction is 42 data. Negative review data included in positive predictions is 47 data and positive review data included in positive predictions is 458 . The results were obtained using the Naive Bayes method based on PSO.

\section{Discussion}

The comparison of the results of comparative Accuracy and AUC Algortima mentioned in table 5 .

Table 5. Comparison of Accuracy and AUC Classification Algorithms

\begin{tabular}{lcc}
\hline Algorithms & Accuracy & AUC \\
\hline SVM & $89.20 \%$ & 0.973 \\
\hline SVM + PSO & $94.60 \%$ & 0.985 \\
\hline Naive Bayes & $88.50 \%$ & 0.536 \\
\hline $\begin{array}{l}\text { Naive Bayes + } \\
\text { PSO }\end{array}$ & $91.10 \%$ & 0.692 \\
\hline
\end{tabular}




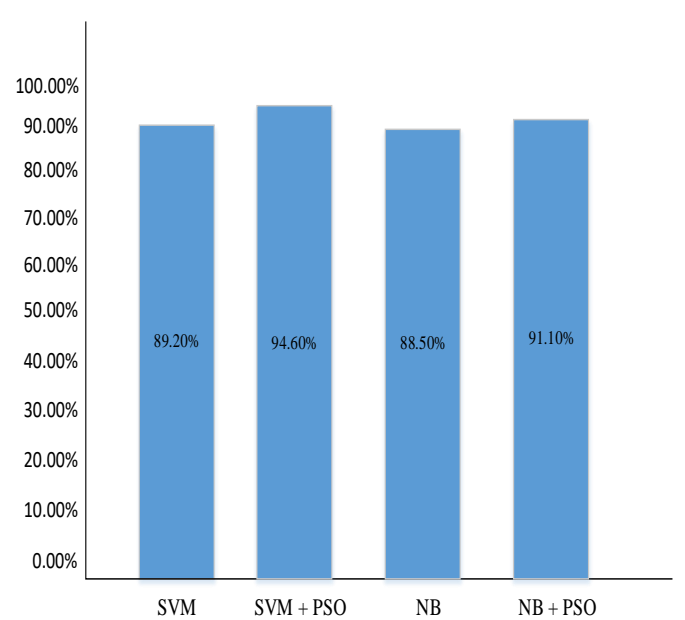

Figure 11. Comparison of Classification Accuracy Algorithms

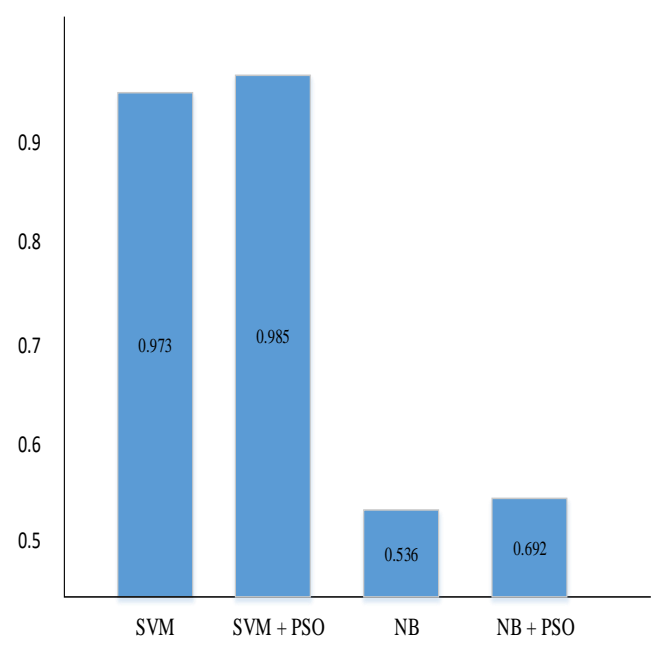

Figure 12. Comparison of AUC Classification Algorithms.

In Figure 11 and Figure 12 it can be seen that the comparison between The Naïve Bayes algorithm and SVM has smaller results compared to PSO-based Naïve Bayes and PSO-based SVM.

Based on tests conducted on cosmetic reviews on the website femaledaily.com which were collected manually consisting of 500 positive reviews and 500 negative reviews. By using the SVM method, SVM based on Particle Swam Optimization (SVM + PSO), Naive Bayes, and Naive Bayes based on Particle Swam Optimization (NB + PSO). In this study, the results of the calculation of the SVM method have an Accuracy of $89.20 \%$ and AUC of 0.973 while the SVM + PSO method produces an Accuracy of $94.60 \%$ and AUC of 0.985 .

Testing has also been compared with the Naive Bayes and Naive Bayes methods based on PSO. Calculation results obtained from testing the data with the Naive Bayes method produce an
Accuracy of $88.50 \%$ and AUC of 0.536 . meanwhile, the PSO-based Naive Bayes method produces an Accuracy value of $91.10 \%$ and AUC of 0.692 .

The application of PSO is proven to be able to improve the accuracy of SVM and Naive Bayes algorithms on the calcification of cosmetic reviews on the femaledaily.com website between positive and negative reviews.

The text classification model in the review data will make it easier for website users especially femaledaily.com to find out which are positive and negative reviews. Based on the review data that has been processed through RapidMiner, the results are separated into basic words after going through the preprocessing stage. These words, each weight so that it can be seen which words are associated with a sentiment that often appears and has the highest weight. Thus it can be seen that the review is included in the positive review and negative review. With this, it can be concluded that SVM based on PSO (SVM + PSO) has a higher accuracy value compared to the Naive Bayes method based on PSO (NB + PSO). Besides, it can also be concluded that PSO optimization can only increase the accuracy value of the Naive Bayes algorithm, especially the Indonesian dataset, in this case, review data taken from products that have the most reviews.

\section{CONCLUSION}

Based on the explanation explained in the previous chapter, the conclusions that can be drawn from this study are based on the formulation of the problem that was made at the beginning of the chapter, namely the application of PSO optimization can improve accuracy and provide a more accurate and optimal solution. Comparison of accuracy resulting from testing this data is SVM Algorithm of $89.20 \%$ and AUC of 0.973 , then with Vector Machine based PSO support with an accuracy of $94.60 \%$ and AUC of 0.985 . the results of data testing for the Naïve Bayes algorithm are $88.50 \%$ accuracy and AUC is 0.536, then its accuracy is compared with PSO based Naïve Bayes by $91.10 \%$ and AUC by 0.692 . The suggestions proposed by researchers are related to the discussion of this thesis, namely in subsequent studies it is recommended to use datasets from different domains, for example, product reviews, film reviews, stock reviews, and so on with Indonesian language texts and examine the optimization of other algorithms to improve accuracy. Using other text classification techniques and other feature selection methods so that the results of the accuracy can be compared. 


\section{REFERENCE}

Buntoro, \& Asrofi, G. (2016). ANALISIS SENTIMEN HATESPEECH PADA TWITTER DENGAN METODE NAÏVE BAYES CLASSIFIER DAN SUPPORT VECTOR MACHINE. Jurnal Dinamika Informatika, 5(2), 1-12. http://ojs.upy.ac.id/ojs/index.php/dinf/artic le/view/975

Buntoro, G. A. (2017). Analisis Sentimen Calon Gubernur DKI Jakarta 2017 Di Twitter | Buntoro | INTEGER: Journal of Information Technology. INTEGER: Journal of Information Technology, 2(1), 32-41. https://ejurnal.itats.ac.id/integer/article/vie $\mathrm{w} / 95$

Chandra, D. N., Indrawan, G., \& Sukaraja, I. N. (2016). Klasifikasi Berita Lokal Radar Malang Menggunakan Metode Naïve Bayes Dengan Fitur N-Gram. Jurnal Ilmiah Teknologi Dan Informasia ASIA (JITIKA), 10(1), 11-19. https://www.jurnal.stmikasia.ac.id/index.ph p/jitika/article/view/62

Faid, M., Jasri, M., \& Rahmawati, T. (2019). Perbandingan Kinerja Tool Data Mining Weka dan Rapidminer Dalam Algoritma Klasifikasi. Teknika, 8(1), 11-16. https://doi.org/https://doi.org/10.34148/te knika.v8i1.95

Kristiyanti, D. A. (2015). ANALISIS SENTIMEN REVIEW PRODUK KOSMETIK MELALUI KOMPARASI FEATURE SELECTION. Konferensi Nasional Ilmu Pengetahuan Dan Teknologi Tahun 2015, 69-76. http://konferensi.nusamandiri.ac.id/prosidi ng/index.php/knit/article/view/33

Kusmira, M. (2019). ANALISIS SENTIMEN REGISTRASI ULANG KARTU SIM PADA TWITTER MENGGUNAKAN ALGORITMA SVM DAN K-NN I INTI Nusa Mandiri. INTI Nusa Mandiri, 14(1), 105-110. http://ejournal.nusamandiri.ac.id/index.php /inti/article/view/541

Mahendrajaya, R., Buntoro, G. A., \& Setyawan, M. B. (2019). ANALISIS SENTIMEN PENGGUNA GOPAY MENGGUNAKAN METODE LEXICON BASED DAN SUPPORT VECTOR MACHINE. KOMPUTEK, $3(2), \quad 52$. https://doi.org/10.24269/jkt.v3i2.270
Pudjiarti, E. (2016). PREDIKSI SPAM EMAIL MENGGUNAKAN METODE SUPPORT VECTOR MACHINE DAN PARTICLE SWARM OPTIMIZATION. Jurnal Pilar Nusa Mandiri, 12(2), 171-181. http://ejournal.nusamandiri.ac.id/index.php /pilar/article/view/271

Rinawati, R. (2013). PENERAPAN PARTICLE SWARM OPTIMIZATION UNTUK SELEKSI ATRIBUT PADA METODE SUPPORT VECTOR MACHINE UNTUK PENENTUAN PENILAIAN KREDIT. Seminar Nasional Ilmu Pengetahuan Dan Teknologi Komputer, 73. http://konferensi.nusamandiri.ac.id/prosidi ng/index.php/sniptek/article/view/309

Rustiana, D., \& Rahayu, N. (2017). ANALISIS SENTIMEN PASAR OTOMOTIF MOBIL: TWEET TWITTER MENGGUNAKAN NAÏVE BAYES. Simetris: Jurnal Teknik Mesin, Elektro Dan Ilmu Komputer, 8(1), 113-120. https://doi.org/10.24176/simet.v8i1.841

Vinodhini, G., \& Chandrasekaran, R. M. (2016). A comparative performance evaluation of neural network based approach for sentiment classification of online reviews. Journal of King Saud University - Computer and Information Sciences, 28(1), 2-12. https://doi.org/10.1016/j.jksuci.2014.03.02 4 
